\title{
Theme Portrayal through Protagonist in Arthur Golden's Memoirs of a Geisha
}

\author{
Adri Christiawan*, Gentara Alam Bumi
}

\author{
English Department, Maranatha Christian University, Bandung, Indonesia
}

\begin{abstract}
This study concerned on the analysis of theme viewed from the portrayal of the main character in Arthur Golden's Memoirs of a Geisha. This study used library research as the methodology and obtained the primary data from the novel, while the supporting data obtained from books and internet sources. The result showed the theme in Memoirs of a Geisha was about achieving a goal, to achieve one's goal, one has to struggle. This was portrayed in 4 characteristics of the main character, Sayuri, who was strong-willed, brave, persistent, and resourceful girl. These characteristic was drawn in Sayuri's attempt in getting close to a man who was giving her a new purpose in her life. Through some difficulties, Sayurifinally succeed in achieving her goal and spent her life with the man she loved.
\end{abstract}

Keywords-Theme, characterization, struggle, goal

\section{INTRODUCTION}

Japan or "Land of the Rising Sun" has a cultural heritage called geisha. Geisha literally means "person of the art". It is a traditional Japanese artist-entertainer who trained to be a dancer, singer, samishen player, and other entertaining skills (Downer 2002). At first, geisha was consisted of men but since the number of men who took the job as a geisha was decreased, women started to take over the job (Dalby, 2005). Geisha is not a prostitute, what geisha really do is entertaining people with skills, witty jokes, and beauty. Geisha was popular in $18^{\text {th }}$ and $19^{\text {th }}$ centuries and still exist today, although the number is dwindling.

Geisha was belonging to the okiya, the house of the geisha. The owner of the okiya treated geisha as property. All the money the geisha girls made went to the okiya because geisha owe the food, the training fee, kimono, and others to the okiya's owner. In order to get the freedom, geisha should either buy themselves out or find a danna, a patron who is willing to buy them out. Arthur Golden captured the life of geisha in 1930s in his novel Memoirs of a Geisha which took ten years to write the novel. Golden did an extensive research about the life of a geisha before World War II. He wrote novel based on a study and an interview with a former geisha who now lives in the USA. He wrote his fiction and nicely combines it with historical events. He gave very detailed description about life in Gion, Kyoto at that time.

Memoirs of a Geisha told about the struggle of a girl named Sayuri who climbed up for her success as a geisha. She was willing to do anything to chase her dream; she let people hurt her, had very hard training, and sold her virginity, due to be together with the man she loves. Sayuri showed that all the hard work will get paid off someday. Therefore, the aim of this study was to reveal the theme of the novel through the portrayal of the main character in the novel.

Theme is a brief mind's full on any particular subject that presents and considers the subject in several of its various aspects. Robert stated that, "theme, like an essay, should be a short, accurate, and forceful presentation of ideas or descriptions, well contrived as totality or unity." (Roberts 8). Meanwhile, a protagonist is the main character in a novel or a film. A protagonist is usually put in a position where the reader is able to empathize with them, basically the central character in a story or narrative.

\section{METHODOLOGY}

This study used library research with descriptive qualitative methodology. Descriptive qualitative methodology used human as the instrument and collected the data from words or action that could be observed (Bogdan and Taylor 1975). This study obtained the primary data from Arthur Golden's Memoirs of a Geisha, while the supporting data obtained from books and internet sources. A careful reading was also done to analyze the theme through the protagonist characterization within the novel.

\section{RESULT AND DISCUSSION}

\subsection{Theme}

The theme of this novel was discussed about goal achievement, which meant that in order to achieve one's goal, someone has to struggle to achieve it. Sayuri, the main character in Memoirs of a Geisha, was experienced some difficulty in her life. She was struggling to get the purpose in her life. Sayuri, the former name is Chiyo, was sold to okiya because her parents cannot take care of her 
and her sister anymore. Sayuri get bullied in okiya by the senior. She was accused for thievery and other horrible things that make her lost her dream and hope. Sayuri had a huge debt that forced her to become a maid for the rest of her life and lose dream;

"I felt like a child lost on a lake in the fog. The days spilled one after another into a muddle" (Golden 122).

The dialogue above showed Sayuri's hopelessness. She could not find any purpose in her life. Until her encounter with the Chairman that gave her a new hope. The Chairman said that, "...that something besides cruelty could be found in the world" (Golden 131). After Sayuri met the Chairman, she found goal in her life. She wanted to be together with the Chairman. Since, being a maid did not give her any chance to achieve her dream, thus, she used every opportunity that she had when there is a second chance for her;

"To become a geisha ... well, that was hardly a purpose in life. But to be a geisha ... I could see it now as a steppingstone to something else" (Golden 131)

She got a second chance and started to work her way up from a maid to a geisha due to achieve her dream.

\subsection{Sayuri's Characterization}

The theme also could be seen through Sayuri's characterization. There were 4 characteristics that led to theme portrayal within the novel, those were; strongwilled, brave, persistent, resourceful.

\section{a. Strong-willed}

According to Oxford Dictionary, strong-willed is very determined to do what a person wants to do ("strongwilled," def.). The protagonist, Sayuri, is strong-willed girl. It can be seen when she tried to find Satsu, her sister. She tried to find information about Satsu because she missed her and she wanted to go back to her home in Yoroido. She even compromises with Hatsumomo, a senior geisha who hates her and sees her as a rival. Sayuri did anything that Hatsumomo told her to do in order to get information about Satsu;

"Hatsumomo-san, I know you don't like me ... If you would be kind enough to tell me what I want to know, I'll promise never to bother you again" (Golden 55). Hatsumomo tells her, "If you want to know where your older sister is, don't make me say anything twice tonight. I have plans for you. Afterward you may ask me a single question, and I'll answer it" (Golden 81).

Hatsumomo wanted Sayuri to ruin Mameha's extravagant kimono. Despite the consequences that she had to bear, Sayuri was very determined to find her sister. She did what Hatsumomo told her to and she finally found out where Satsu is; "is in ajorou-ya called Tatsuyo ... in the district of Miyagawa-cho, just south of Gion" (Golden 89).

Another strong-willed characteristic was drawn when Sayuri got another chance to be a geisha. Sayuri wanted to be a geisha because she wanted to be closed to the Chairman. Sayuri realized that it was impossible for her to be with the Chairman if she is just a maid. For her, being a geisha is the only way to be together with the Chairman. Thus, when Sayuri had another chance to become a geisha, she did not waste it and tried her best. She did it for one goal, to be with the Chairman;

"I would suffer through any training, bear up under any hardship, for a chance to attract the notice of a man like the Chairman again" (Golden 132). The quotation showed Sayuri determination to be together with the Chairman.

It was also seen when Sayuri practicing her skills. After she got back to the geisha school, she still had to run errands in her okiya. She said, "What makes a geisha's training- so difficult isn't simply the arts she must learn, but how hectic her life becomes. After spending all morning in lessons, she is still expected to work during the afternoon and evening very much as she always has. And still, she sleeps no more than three to five hours every night" (Golden 167). If she wanted to be a successful geisha, she must be able to perform almost every art that exists at that time. She reminds herself that "I had longed for nothing so much as the chance to become a geisha and find a place for myself in the world" (Golden 176). The quotation showed that Sayuri was very determined to achieve her goal. It enables her to work and practice her skill at the same time. She knew that being a geisha was her only way to be with the Chairman and if she wants to become a geisha, she must be able to perform everything she learned from the school. She knew that if she fails to do so, it meant the end of her dream.

Her strong will also can be seen when Nobu tried to propose to become her danna. Since Sayuri started her career as an apprentice Geisha, Mameha already had a plan to make Nobu as Sayuri's danna. A month after Sayuri became a full-time Geisha, Nobu proposed to become her danna. Sayuri told Mameha that she did not want Nobu to be her danna. The reason was because Nobu and the Chairman are good friends. Also, if Nobu became Sayuri's danna, her dream to be together with the Chairman will never come true. Although Nobu was very kind and fond of Sayuri, Sayuri wanted something more than just kindness. Mameha said, "We don't become geisha so our lives will be satisfying. We become geisha because we have no other choice" (Golden 344). But Sayuri saw differently, for her, being a geisha as a stepping stone, not as the last option. Sayuri asked Mameha whether she ever 
had a feeling for someone. She made Mameha think about her own feelings. Finally, Mameha convinced Mother to turn down Nobu's proposal.

However, after World War II, Nobu tried to propose to become her danna again. At this point, she had already spent so much time together with Nobu and she hardly had any connection with the Chairman. She confused whether accepting Nobu's proposal or not. She thinks that Nobu is probably a very desirable danna, but wonders if she could bear to live a life in which her hopes have been extinguished forever (Golden 461). In the end, she does not want to give up her dream for someone as nice as Nobu. She plots a scheme to make Nobu angry at her and draw back his proposal. She manages to make Nobu do so.

From her strong-willed characteristic, it can be perceived that strong will make her determine to do almost anything to achieve a goal. Therefore, Sayuri tried very hard to achieve her goal, as stated in the theme above "In order to achieve one's goal, someone has to struggle to achieve it."

\section{b. Brave}

Her second characteristic is brave. Brave meant ready to face and endure danger or pain ("brave," def.). Sayuri bravery can be seen from her decision to become a geisha and to endure the painful process of being a geisha;

"The problem, as I later learned, was that in her geisha days she'd used a kind of white makeup we call "China Clay," made with a base of lead. China Clay turned out to be poisonous, to begin with, which probably accounted in part for Granny's foul disposition" (Golden 53).

Sayuri knew that the makeup she wore was poisonous. But she kept wearing it in order to become a geisha. She even endured the danger of wearing poisonous makeup. She knew the fact but still took the risk of wearing makeup to become a geisha until the Chairman proposes her. Another example of her bravery can be seen from the quotation:

It says a great deal about how civilized we human beings are, that a young girl can willingly sit and allow a grown man to comb wax through her hair without doing anything more than whimpering quietly to herself. If you tried such a thing with a dog, it would bite you so much you'd be able to see through your hands. (Golden 190).

Sayuri realizes that applying wax to her hair is painful. Furthermore, the pain does not stop there, she had to sleep on a cradle that support her neck to maintain her hairstyle. She had to bear the pain not only when the hairdresser applies the wax, but also when she tried to sleep after that. If she sleeps without the cradle, her hair will be flattened out of shape, and she will have to go to the hairdresser again.

Her bravery was also seen when she let Mameha purposely cut her thigh. The cut itself may cause an infection or leave a scar and it was painful. She was also afraid of blood. She said "I'd be lying if I said I wanted to obey her; but of course, I had no choice“ (Golden 250). Despite all the risks, Mameha told her that it can help her to improve her career. She finally let Mameha do so. Afterwards, Sayuri and Mameha went to a doctor who has an interest in the young geisha to take care of the wound, and this doctor has a role in improving her career. This pain finally got paid off because the doctor was finally attracted to Sayuri and he bought Sayuri's virginity.

Her bravery also can be seen when she sells and sacrifices her virginity in order to become a famous geisha in Gion. When a geisha is going to sell her virginity, she has to hold an auction and present an $e k u b o$ or a rice cake to the potential buyers who are willing to bid for the geisha's virginity. She gives the ekubo to only two men who put an interest in her. "Most apprentices give them out to at least a dozen men, perhaps many more; but for me there would be only Nobu and the Doctor-if we were lucky" (Golden 278). This is may be risky for her because there might be only two possible buyers who would be interested in buying her virginity. With only two possible buyers, the competition would not be so intense. If that happens, it is possible that she may have to sell her virginity at a very low price. Geisha's virginity is the biggest asset that she has to pay her debt. It is impossible to pay her debt by only depending on her income because geisha must split their income with the teahouse, the okiya, and the geisha as sociation. Since virginity can be sold one time only, it is important to sell it at a high price to drastically reduce the debt; or else, she will never be able to pay off her debt.

Her bravery can also be seen when she endures the pain of practicing shamisen. She says, "In winter, both Pumpkin and I were made to toughen up our hands by holding them in ice water until we cried from pain, and then practice outside in the frigid air of the courtyard" (Golden 167). She does it so that not only can she play the shamisen better, but she can also overcome her stage fright. She deals with the pain caused by the ice until her fingers become numb. Despite the pain or the risk of getting frostbitten, she can finally play better and she does not have a stage fright anymore.

Her bravery showed that people have to be brave to make a tough decision in order to achieve their goal. People are forced to make a choice despite the risk that may occur from one's decision. This is in line with the theme "In order to achieve one's goal, one has to struggle 
to achieve it." The time people are facing difficulties is the time when people need to be brave to face these problems, and bravery helps us to struggle.

\section{c. Persuasive}

Another characteristic of Sayuri's is persuasive. Persuasive means "able to persuade somebody to do or believe something" ("persuasive," def.). When Mameha sends her maid to ask Sayuri to come to Mameha's place, Sayuri tries to find a reason to go out and come to Mameha. The maid asks, "Are you sent on errands from time to time, Chiyo? ... Arrange for yourself to be sent out tomorrow afternoon at three o'clock, and meet me at the little bridge that arches over the Shirakawa Stream" (Golden 138). She asks for Pumpkin's help to find a reason for her to go out for a while to meet Mameha. At first, Pumpkin does not want to help Sayuri because she is afraid if someone in the okiya finds out, she will be in trouble. Pumpkin is worried about getting into trouble, until Sayuri promises to find a way of repaying her (Golden 138). Pumpkin helps her by asking Sayuri to do some errands. She manages to ask for a help from Pumpkin and finally has a reason to go out.

Another example of her being persuasive is when she asks Pumpkin what Hatsumomo has told Dr. Crab. Dr. Crab suddenly does not want to talk with Sayuri and Mameha anymore. Sayuri tries to ask Pumpkin what Hatsumomo has done. Sayuri says, "You were in the room earlier this evening when Hatsumomo talked with the Doctor. I'm afraid my whole future may be affected by that conversation. Hatsumomo must have told him something about me that isn't true, because now the Doctor doesn't want to see me any longer" (Golden 275). At first, Pumpkin does not want to tell her because she is told by Hatsumomo to do something and she is very tired by then. Sayuri tells Pumpkin to sit down and do the errands for Pumpkin. After she is back, Sayuri tries to comfort Pumpkin because of her miserable condition caused by Hatsumomo. Sayuri takes Pumpkin's handkerchief and tries to smooth the makeup on Pumpkin's face. Sayuri feels so touched at seeing the old Pumpkin again, who had once been her friend, that Sayuri's eyes grow watery as well, and they end up in an embrace (Golden 275). Afterwards, Pumpkin says "I want to help you Chiyo." (Golden 276). Pumpkin finally tells Sayuri what has happened and why Dr. Crab does not want to see them anymore. Pumpkin tells Sayuri how Hatsumomo has manipulated Dr. Crab by telling a lie to him. According to Hatsumomo, Sayuri already has a boyfriend and she is not a virgin anymore

From her characteristic of being persuasive, it can be perceived that people have to be persuasive to get what they want. Being persuasive helps people to get what they want. If people can win the argument on two conflicting ideas, people already get what they want. It is related to the theme that "In order to achieve one's goal, one has to struggle to achieve it." Being persuasive is an effort that helps to achieve what one wants.

\section{d. Resourceful}

Another Sayuri's characteristic is resourceful. Resourceful means able to find and use different ways to help achieve your goals ("resourceful," def.). It can be seen when she tries to run away. Mother finds out that Sayuri has gone out when she is not supposed to. After that, the door of the okiya is locked and only Mother and Auntie have the key. Having only few days, Sayuri tries to find another way to run away. When she is cleaning the floor, an idea struck her head.

The roof! I was so astonished at the thought, I forgot my surroundings completely; and when the telephone near Yoko rang, I almost cried out in alarm. I wasn't sure what I would do once I reached the roof, but if I could succeed in finding my way down from there, I might meet Satsu after all. (Golden 107)

She has an idea of running away even though the front door is locked. When the night comes, she makes sure everyone has fallen asleep, and she climbs the roof and continues with her plan to run away.

Another example of her being resourceful is when she tries to seduce Dr. Crab again. They are attending a party and Sayuri has been instructed to make both Nobu and Dr. Crab interested in her. She uses the wound on her thigh to seduce Dr. Crab. She says that the wound has left a little tiny bump and then she says, "Perhaps it isn't as big as I've said. After all, my leg is very ... well, sensitive, you see. Even just a drop of rain falling onto it is enough to make me shudder!" (Golden 288). She utilizes the scar on her thigh to make Dr. Crab more interested inn buying her virginity. She knows that Dr. Crab has an interest in her and she tries to make him more interested by seducing Dr. Crab using the scar on her thigh.

Another example of her being resourceful is when she finally meets Nobu after she has got a danna. Because Nobu's proposal has been turned down, Nobu does not want to see Sayuri anymore. Without Nobu, she is no longer invited to Iwamura Electric's party and that means it becomes harder for her to meet the Chairman. Finally, Sayuri finds out that Nobu still often comes to Gion but never to see Sayuri. Nobu comes to the tea house that has no partnership with Sayuri. However, this does not stop her from meeting Nobu. Sayuri strolls for eight or nine weeks in front of Awazumi tea house, hoping that she will eventually be able to meet Nobu. She uses his knowledge about Nobu's habit so that she can predict what time Nobu 
may arrive. She says, "I knew his habits well enough to make a fair guess about the time he might arrive" (Golden 363). She is finally able to meet Nobu in front of the tea house.

Another example of Sayuri's resourcefulness is when she tries to find a way to refuse Nobu who proposes to be her danna. Nobu is the Chairman's best friend; he even owes Nobu his life. If Nobu became Sayuri's danna, it would be impossible for Sayuri to be together with the Chairman anymore. The Chairman would never steal something that is so special from his best friend, which, in this case, is Sayuri. Nobu cannot stand the image of Sayuri being with another man. Nobu states that "If I was the sort of woman who would give myself to the Minister, he'd said, he wanted me to leave the room right then and would never speak to me again" (Golden 460). Knowing this fact, Sayuri tries to find an opportunity to throw herself on the Minister when they are on a holiday at Amami. She tries to use Nobu's jealously to break his heart. She knows that Nobu does not want to see or even imagine her being with another man. Although her plan does not turn out the way she has expected, Nobu becomes angry at her and finally does not want to be Sayuri's danna anymore.

From her characteristic of being resourceful, it can be perceived that one should be resourceful in order to get what one wants. Being resourceful makes people able to overcome difficulties that may occur in our path to achieve goal. This is in line with the theme, "In order to achieve one's goal, one has to struggle to achieve it." Therefore, from Sayuri's characterization it showed that the theme depicted in the novel is to achieve one's goal, one has to struggle to achieve.

\section{CONCLUSION}

After analyzing the theme through the portrayal of the protagonist in Arthur Golden's Memoirs of a Geisha, the conclusion is Sayuri, the protagonist, is sold to be a geisha because her parents cannot take care of her anymore. Because of her mistake, she lost her chance to be a geisha and becomes a maid, and owes an even greater debt. She can repay her debt only by being a maid as long as she lives. When she had lost all her hope and purpose of life, the Chairman came and brought her life another purpose. From here, Sayuri wanted to be together with the Chairman and worked her way up from being a maid to be a geisha.

The theme was about goal achievement which seen through Sayuri's characteristic as a strong-willed, brave, persistent, and resourceful girl. Sayuri had faced some difficulties in her life and overcome the difficulties in her life with those characteristics. Sayuri's characteristic of being strong-willed helps her become determined in achieving her goal. When she sets her new goal after her encounter with the Chairman, she works very hard to achieve it. As she goes through a very hard training and a painful process of being a geisha, she finds a way to practice her skill amid her hectic schedule as a maid and as a student of a geisha school. With this characteristic, she lives her life doing everything that she can to achieve her goal. She goes through all of the process of being a geisha and finally she achieves her goal.

Being brave, also enables her to overcome the obstacles that occur in her way to becoming a geisha. She endures the risk of wearing a poisonous make up, lets someone apply a hot wax on her hair although it is painful, and sleeps with a cradle that supports her neck. She does anything just to get herself a step closer to her goal. Her bravery helps her to encourage herself to do things that are painful and uncomfortable in order to improve her career and make herself a step closer to her goal.

Persistent helps her to focus on her goal. Even when Nobu is already fond of her, she does not take her eyes off from the Chairman. She knows that Nobu is a fine and nice man, but she does not love him. She wants something more than just kindness and she can get it only if she is together with the Chairman. Therefore, every time Nobu proposes to be her danna, she turns him down. She knows that Nobu's kindness would not make her happy. She keeps on chasing the Chairman because she knows that she will be happy if she is together with the Chairman.

Her last characteristic is resourceful. It helps her to find a way to resolve the problems that come her way. For example, she seduces the man who has an interest in her by using the scar on her thigh. She uses her femininity and acts so innocent in front of Dr. Crab. She knows the fact that the doctor loves buying geisha's virginity and probably will buy hers too. She uses her scar to sexually attract Dr. Crab. From this quality of hers, she can find a solution to deal with her problem. Although there are only two men who bid on her virginity, Dr. Crab pays an outstanding amount of money for her virginity.

The protagonist, Sayuri, is portrayed as someone who is different from the other geisha girls. The other geisha girls become geisha because they do not have any other option. But Sayuri, becomes a geisha as a stepping stone for something greater, not as a dead end.

\section{REFERENCES}

[1] Bogdan, Robert., and Taylor, Steven J. Introduction to Qualitative Research Method. New York: John Willey and Sons, 1975

[2] Dalby, Liza. Geisha. Vintage: London, 2005 
[3] Downer, Lesley. Women of the Pleasure Quarters The Secret of History of Geisha. Broadway Books, 2002.

[4] Golden, Arthur. Memoirs of a Geisha. New York: Vintage Contemporaries, 1997

[5] Roberts, Edgar V. Writing Themes About Literature. New Jersey: Prentice-Hall, Inc, 1977

[6] "Brave". Oxford Dictionary. Oxford University Press. Web. Sept 13, 2011.

[7] "Strong-willed". Cambridge Dictionaries Online. Cambridge University Press, 2011.Web. Oct 28, 2011.

[8] "Persistent". Cambridge Dictionaries Online. Cambridge University Press, 2011.Web. Oct 28, 2011.

[9] "Resourceful". Cambridge Dictionaries Online.

Cambridge University Press, 2011.Web. Oct 28, 2011. 